\title{
Socio-Economic and Demographic Correlates of Infant and Child Mortality: The Case of Slum Areas in Rajshahi District of Bangladesh
}

\author{
Kamal Hossain, Md. Rafiqul Islam*, Md. Quamrul Hasan Chowdhury
}

Department of Population Science and Human Resource Development, University of Rajshahi, Bangladesh

\begin{abstract}
The aim of this study is to identify the important effects of socio-demographic characteristics on infant and child mortality. For this reason, data were collected from slum areas of Rajshahi City Corporation at Rajshahi district in Bangladesh through purposive sampling technique. Chi-square test, correlation and multiple coefficients of determination techniques have been employed for analyzing the differential patterns, interrelationships and effects of socio-demographic correlates on infant and child death. Education of parents, income of household, occupation, age at first marriage and breastfeeding are significantly associated with infant and child death. The combined effects of social and demographic variables are wholly explained $46.2 \%$ and $82.5 \%$ for both infant and child death respectively. Therefore, female education, age at first marriage as well as income level should be increased at any cost to ensure reducing death of infant and child.
\end{abstract}

Keywords Neonatal, Post neonatal, Infant and Child mortality, Socio-economic and demographic characteristics, Chi-square $\left(\chi^{2}\right)$ test, Multiple coefficient of determination $\left(\mathrm{R}^{2}\right)$

\section{Introduction}

Bangladesh is one of the most densely populated countries comprising 1, 47,570 square kilometers area with accelerated population growth. In last few decades, infant and child health have been brought significant improvements. According to Population and Development Indicators for Asia and the Pacific report, 2008, in SAARC countries' infant and under five mortality rates in Bangladesh were 52 and 68 per 1,000 live births respectively which are still very high ${ }^{1}$.

Many studies have shown that the infant and child mortality influenced by a number of socio-economic and demographic factors such as sex of the child, mother's age at birth, birth order, preceding birth interval and survival of preceding sibling(s) were the most important determinants of infant and child mortality in Bangladesh ${ }^{2,3,4,5}$. In socioeconomical aspect, Bangladesh is comparatively disadvantage in terms of child mortality indicator as per capita GNI recently crossed the USD $\$ 500$ and it is forecasted to continue to rise ${ }^{6}$.

Many studies showed that low economic status is associated with increased rates of infant and child mortality ${ }^{7,8,9,10}$. Socioeconomic status is also strongly related to maternal education level, which impacts on the risk of disease through

* Corresponding author:

rafique_pops@yahoo.com (Md. Rafiqul Islam)

Published online at http://journal.sapub.org/ijpt

Copyright (C) 2012 Scientific \& Academic Publishing. All Rights Reserved child-rearing practices such as breastfeeding, appropriate care-seeking ${ }^{11}$. Caldwell argued the maternal education of women plays an important role in determining child survival even after controlling for a number of socioeconomic factors $^{12}$. Several other studies also established the influence of maternal education on infant and child mortality ${ }^{13,14,15}$.

Hong and Rathavuth showed that levels of infant and child mortality in many developing countries remain unacceptably high, and they are disproportionably higher among high-risk groups such as newborn and infant of multiple births ${ }^{16}$. A number of studies have revealed that the influence of maternal age at delivery on the health and survivorship of children $^{17,18,19,20}$. Rahman et al. show that the risk of infant and child mortality is higher for children whose mothers never breast-feed than for children who are breast-feed ${ }^{21}$.

Therefore, the fundamental objective of this study is to identify the effects of socio-demographic correlates on infant and child mortality.

\section{Sources of Data}

This study was followed a personal interview approach for the purpose of data collection and took direct interview of women with the help of questionnaire. In order to observe the effects of the socioeconomic and demographic variables, 200 data were collected from slum area of Rajshahi City Corporation of Rajshahi district in Bangladesh from 1st-30th June 2006 out of 1276 respondents aged 15-49 years. We have chosen purposively university station slum area, shirol 
slum area, Mirjapur slum area and slum area of the Padma bank of Rajshahi City Corporation under Rajshahi district. Statistical Package for Social Sciences (SPSS), version 10.0 package program has been used for analyzing the data.

\section{Methodology of this Study}

The contingency analysis is used to test significance between the different phenomena on the basis of classification of variables or attributes by applying the Chi-square $\left(\chi^{2}\right)$ test in which $\chi^{2}=\sum \frac{o_{i j}}{E_{i j}}-N$, follows $\chi^{2}$ distribution with $(\mathrm{r}-1)(\mathrm{c}-1)$ degrees of freedom ${ }^{22}$.

Correlation coefficient (r $)$ is used in this study to see the positive or negative correlation of infant and child mortality with socio-demographic variables, all explanatory variables are numerical as education 0 year, 1 year, 2 years,..., 16 years, income $1000,2000, \ldots$. Therefore, it has no restriction to employ Pearson correlation statistic in this study. Symbols used in this study, where, $\mathrm{X}_{1}=$ Age at first marriage, $\mathrm{X}_{2}=$ Women education, $\mathrm{X}_{3}=$ Monthly income, $\mathrm{X}_{4}=$ Breast feeding, $\mathrm{X}_{5}=$ Children ever born, $\mathrm{Y}=$ age at death of infant and child as dependent variable.

Multiple coefficient of determination $\left(\mathrm{R}^{2}\right)$ is used for explaining the multiple effects of socioeconomic and demo- graphic attributes on infant and child mortality. It is noted that coefficients of determination are obtained from the multiple regression models in which explanatory variables are all quantitative ${ }^{22}$. Further, for differentiality and association of socio-demographic characteristics between infant and child mortality, both dependent and independent variables are categorized.

\section{Results and Discussion}

In the Table 1, it is observed that most of women (36.5\%) illiterates, $32.5 \%$ primary level and $31 \%$ secondary and higher level of education. Respondents' husband has $38 \%$ illiterate, $30 \%$ primary education, $29.5 \%$ secondary education and only $2.5 \%$ of them have higher education. In our study area, $68.5 \%$ respondent's house was made of tin, $19.5 \%$ semi-building, 9\% building. Families earn per month 2500-3500 Tk. (53.5\%) and $23.5 \%$ exist in the range 1500-2500 Tk. Most of women (83\%) occupations were housewife. On the other hand, 38.5\% respondent's husbands were labors, $24 \%$ in job, $21 \%$ in business and $11.5 \%$ in other occupations. In the study area, $42 \%$ women have occurred early marriage i.e; before age 15 years, $56 \%$ occurred within years $16-20$ years. Women have breast-fed their children above 2 years $(47.5 \%), 28 \%$ breast-fed 2 years and $17.5 \%$ breast-fed their babies less than 1 year.

Table 1. Percentage of Women Aged 15-49 Years According to Some Selected Socio-Economic Characteristics in Slum Areas of Rajshahi City Corporation, Bangladesh.

\begin{tabular}{|c|c|c|c|c|c|}
\hline $\begin{array}{c}\text { Background } \\
\text { characteristics }\end{array}$ & $\begin{array}{r}\text { Number } \\
\text { of cases }\end{array}$ & Percentages & $\begin{array}{c}\text { Background } \\
\text { characteristics }\end{array}$ & $\begin{array}{r}\text { Number } \\
\text { of cases }\end{array}$ & Percentages \\
\hline $\begin{array}{c}\text { Educational qualification } \\
\text { of women } \\
\text { Illiterate } \\
\text { Primary } \\
\text { Secondary and higher } \\
\text { Total } \\
\text { Educational qualification } \\
\text { of husband } \\
\text { Illiterate } \\
\text { Primary } \\
\text { Secondary } \\
\text { Higher } \\
\text { Total } \\
\text { Household condition } \\
\text { Tin } \\
\text { Building } \\
\text { Semi building } \\
\text { Kacha } \\
\text { Total } \\
\text { Monthly income } \\
<1500 \text { taka } \\
1500-2500 \text { taka } \\
2500-3500 \text { taka } \\
3500-9500 \text { taka } \\
9500+\text { taka } \\
\text { Total }\end{array}$ & $\begin{array}{c}7 \\
47 \\
107 \\
25 \\
14 \\
200\end{array}$ & $\begin{array}{c}3.5 \\
23.5 \\
53.5 \\
12.5 \\
7.0 \\
100.0\end{array}$ & $\begin{array}{c}\text { Occupation of women } \\
\text { House wife } \\
\text { Job } \\
\text { Business } \\
\text { Others } \\
\text { Maid servant } \\
\text { Total } \\
\text { Occupation of husband } \\
\text { Labor } \\
\text { Business } \\
\text { Job } \\
\text { Others } \\
\text { Total } \\
\text { Age at first marriage } \\
<15 \text { years } \\
16-20 \text { years } \\
21-24 \text { years } \\
>24 \text { years } \\
\text { Total } \\
\text { Duration of } \\
\text { Breast-feeding } \\
<1 \text { years } \\
2 \text { years } \\
>2 \text { years } \\
\text { Total }\end{array}$ & $\begin{array}{c}166 \\
2 \\
6 \\
20 \\
6 \\
200 \\
\\
77 \\
42 \\
48 \\
23 \\
190 \\
\\
84 \\
112 \\
3 \\
1 \\
200\end{array}$ & $\begin{array}{c}83.0 \\
1.0 \\
3.0 \\
10.0 \\
3.0 \\
100.0 \\
\\
38.5 \\
21.0 \\
24.0 \\
11.5 \\
95.0 \\
\\
42.0 \\
36.0 \\
1.5 \\
0.5 \\
100.0\end{array}$ \\
\hline
\end{tabular}


Table 2. Distributions of Infant and Child Mortality According to Socio-Economic and Demographic Attributes

\begin{tabular}{|c|c|c|c|c|}
\hline \multirow{2}{*}{ Attributes } & \multicolumn{2}{|c|}{ Infant } & \multirow{2}{*}{ Child } & \multirow{2}{*}{$\begin{array}{c}\text { Results of contingency } \\
\text { analysis }\end{array}$} \\
\hline & Neonatal & Post-neonatal & & \\
\hline \multicolumn{5}{|l|}{ Educational qualification of women } \\
\hline (respondent) & $10(43.5 \%)$ & $3(13.0)$ & $10(43.5)$ & \\
\hline Illiterate & $6(75.0 \%)$ & $1(12.5)$ & $1(12.5)$ & $\chi^{2}=18.642$ \\
\hline $\begin{array}{l}\text { Primary } \\
\text {. }\end{array}$ & - & - & $4(100.0)$ & $\mathrm{df}=2$ \\
\hline Secondary and higher & $16(45.7 \%)$ & $4(11.4)$ & $15(42.9)$ & $\begin{array}{l}\rho=0.037 \\
\gamma^{2}=0488\end{array}$ \\
\hline \multicolumn{5}{|l|}{ Educational qualification of husband } \\
\hline Illiterate & $10(500)$ & $1(5)$ & & \\
\hline Primary & $4(44.4)$ & $\begin{array}{ll}3(33,3) \\
1(3)\end{array}$ & $\begin{array}{l}9(45.0) \\
2(22.2)\end{array}$ & $\chi^{2}=17.3181$ \\
\hline Secondary and higher & $\begin{array}{l}4(44.4) \\
2(33.3)\end{array}$ & $\begin{array}{c}- \\
-32.01\end{array}$ & $4(66.7)$ & $\mathrm{df}=2$ \\
\hline Total & $16(45.7)$ & $4(11.4)$ & $15(42.9)$ & $\rho=0.024$ \\
\hline Household condition & & & & $\chi_{\text {tab }}^{2}=9.488$ \\
\hline $\begin{array}{l}\text { Tin } \\
\text { Building }\end{array}$ & $14(53.8)$ & $4(15.4)$ & $8(30.8)$ & $\gamma^{2}=16320$ \\
\hline Building & $1(20.0)$ & - & $4(80.0)$ & $\begin{array}{c}\chi-16.320 \\
d f=?\end{array}$ \\
\hline Semı buildıng & $1(25.0)$ & - & $3(75.0)$ & $0=0.048$ \\
\hline $\begin{array}{l}\text { Total } \\
\text { Monthly income }\end{array}$ & $16(45.7)$ & $4(11.4)$ & $15(42.9)$ & $\begin{array}{c}\rho=0.048 \\
\gamma^{2}=9488\end{array}$ \\
\hline$<1500$ & & & & $\chi_{\mathrm{tab}}=9.488$ \\
\hline $1500-2500$ & $9(64.28)$ & $3(21.43)$ & $2(14.29)$ & $\chi^{2}=16735$ \\
\hline $2500-3500$ & $7(53.8)$ & $1(7.7)$ & $4(25.0)$ & $\mathrm{df}=3$ \\
\hline $3500+$ & - & - & $5(38.5)$ & $\rho=0.029$ \\
\hline Total & $\begin{array}{c}- \\
16(457)\end{array}$ & - & $4(100.0)$ & $\chi_{\mathrm{tab}}^{2}=12.592$ \\
\hline Occupation of respondent & $16(45.7)$ & $4(11.4)$ & 15 (42.9) & \\
\hline Housewife & $13(500)$ & $3(115)$ & & $\chi^{2}=14.517$ \\
\hline Business and services & $13(50.0)$ & $3(11.5)$ & $\begin{array}{l}10(38.5) \\
2(1000)\end{array}$ & $\mathrm{df}=2$ \\
\hline Maid servant and others & $3(42) \div$ & ${ }^{-}$ & $2(100.0)$ & $\rho=0.036$ \\
\hline Total & $3(42.86)$ & $1(14.28)$ & $3(42.86)$ & $\chi_{\mathrm{tab}}^{2}=5.991$ \\
\hline Occupation of husband & $16(45.1)$ & $4(11.4)$ & $15(42.9)$ & \\
\hline Labor & $5(31.25)$ & $3(18.75)$ & $8(50.00)$ & $\chi^{2}=3.313$ \\
\hline Business and job & $9(60.0)$ & $1(6.67)$ & $5(33.33)$ & $\mathrm{df}=2$ \\
\hline Others & $2(50.0)$ & - & $2(50.0)$ & $\rho=0.769$ \\
\hline $\begin{array}{l}\text { Total } \\
\end{array}$ & $16(45.7)$ & $4(11.4)$ & $15(42.9)$ & $\chi_{\mathrm{tab}}^{2}=5.991$ \\
\hline $\begin{array}{l}\text { Age at first marriage } \\
10-14\end{array}$ & & & & \\
\hline $\begin{array}{l}10-14 \\
15-10\end{array}$ & $11(44.0)$ & $3(12.0)$ & $11(44.0)$ & $\chi^{2}=6.306$ \\
\hline $15-19$ & $4(44.44)$ & $1(11.11)$ & $4(44.44)$ & $\mathrm{df}=2$ \\
\hline $20+$ & $1(100.00)$ & - & $\begin{array}{c}4(4+.44) \\
-\end{array}$ & $\rho=0.043$ \\
\hline $\begin{array}{l}\text { Total } \\
\text { Breat feeding }\end{array}$ & $16(45.7)$ & $4(11.4)$ & $15(42.9)$ & $\chi_{\mathrm{tab}}^{2}=5.991$ \\
\hline Breast feeding & & & & \\
\hline $\begin{array}{c}0-1 \text { year } \\
1-2\end{array}$ & $16(61.54)$ & $4(15.38)$ & $6(23.08)$ & $\chi^{2}=12.838$ \\
\hline $\begin{array}{l}1-2 \\
2+\end{array}$ & - & - & $5(100.0)$ & $\mathrm{df}=2$ \\
\hline $2+$ & - & - & $4(100.0)$ & $\rho=0.047$ \\
\hline $\begin{array}{l}\text { Total } \\
\text { CFB }\end{array}$ & $16(45.7)$ & $4(11.4)$ & $15(42.9)$ & $\chi_{\text {tab }}^{2}=5.991$ \\
\hline$<=3$ & & & & $\alpha^{2}=0775$ \\
\hline 4 & 4(44.4) & 1(11.1) & 4(44.4) & $\begin{array}{c}d f=2 \\
-0.11\end{array}$ \\
\hline 5 and $a b$ & $5(38.5)$ & $2(15.4)$ & $6(46.2)$ & $=0.942$ \\
\hline Total & $7(53.8)$ & $1(7.0)$ & $5(38.5)$ & $\gamma^{2}=5991$ \\
\hline Fotal & $16(45.7)$ & $4(11.4)$ & $15(42.9)$ & $\chi$ tab $-J .9$ \\
\hline
\end{tabular}

Note: The values within the bracket indicate the percentage value.

\subsection{Differential Patterns of Infant and Child Mortality}

Table 2 represents the infant and child mortality differentials and statistical association with socio-demographic characteristics. The results reveal that illiterate women have higher (43.5\%) both neonatal and child mortality level and haven't higher infant mortality level in primary, secondary and higher educated women. There exist association between women education and infant and child mortality at 5\% level of significance. In case of respondents' husband education, the higher level mortality have in neonates $(50 \%)$ and post-neonates $(45 \%)$ those illiterate but child mortality level is high $(66.7 \%)$. Respondent's husband education is also statistically significant at $5 \%$ level.

Respondent's lower monthly income $(<1500$ Taka) have higher neonatal mortality (64.28\%) and lower level of mortality both infant and child whose monthly income of households are high. Condition of dwelling place-made of tin is higher level of neonatal mortality $(53.8 \%)$ and in case of building and semi-building have higher level of child mortality $80 \%$ and $75 \%$ respectively. Both respondent's monthly income and condition of households are statistically significant at $5 \%$ level with infant and child mortality. 
Respondent's of whom are housewives they have higher level of neonatal mortality (50\%) but lower level mortality among business and service holders. While child mortality shows higher $(100 \%)$ of business and service holders women. Highest neonatal mortality pattern exist of respondent's husband occupation are business and job holders $(60 \%)$. Occupations of respondent's are statistically significant at 5\% level but insignificant of husband's occupation with infant and child mortality.

Early age at first marriage is an important determinant of infant and child survival and nutritional improvements. It is evident from result that respondent's age at first marriage occurring early i.e; $10-14$ years both neonatal and child mortality level are $44 \%$, and $12.0 \%$ post-neonatal mortality. Both neonatal and child mortality (44.40\%) occur for the mother whose age at marriage is in $15-19$ years and $11.11 \%$ in post neonatal level. The propensity of infant and child mortality to the mother of who age at first marriage is lower as comparing to the older age of mother. Age at first marriage of respondent's and infant and child mortality have an association at $5 \%$ level of significance.

Results indicate that highest neonatal mortality $(61.54 \%)$ occur who are breast-feed $0-1$ years, $15.38 \%$ in post neonatal level and $23.08 \%$ in child age. Only child deaths occur who are breast-feed 1-2 years and 2+ years. Breast-feeding and infant and child mortality is statistically significant at $5 \%$ level. It is also observed that highest neonates' mortality (53.8\%) for the mother who have given birth 5+ and child mortality is highest $(46.2 \%)$ to the mother who have given birth 4 . In case of CEB, it is seen that there is no association between CEB and infant and child mortality at 5\% level.

\subsection{Interrelationship between Infant and Child}

\section{Mortality with Socioeconomic and Demographic Characteristics}

Correlation analysis shows in Table 3 that infant and child mortality is negatively significantly correlated with women education $\left(-0.253^{* *}\right)$, husband education $\left(-0.248^{* *}\right)$, age at first marriage $(-0.204 * *)$ and breast-feeding $(-0.347 *)$. That is, if educational qualification of parents and age at first marriage increase then mortality will begin to decrease. Through our correlation results, interrelationship of socioeconomic variables on infant and child mortality can be shown in figure-1, where we can see in flow chart that infant and child mortality is negatively significantly correlated with parents' education, age at marriage and breast-feeding.

Table 3. Correlation of Age at Death of Infant and Child with Socio-Economic and Demographic Variables

\begin{tabular}{|c|c|c|c|c|c|c|c|}
\hline Variable & $\begin{array}{c}\text { Age at death of } \\
\text { infant and child }\end{array}$ & $\begin{array}{c}\text { Women } \\
\text { education }\end{array}$ & $\begin{array}{c}\text { Husband } \\
\text { education }\end{array}$ & $\begin{array}{c}\text { Monthly } \\
\text { income }\end{array}$ & $\begin{array}{c}\text { Age at first } \\
\text { marriage }\end{array}$ & $\begin{array}{c}\text { Breast } \\
\text { feeding }\end{array}$ & $\begin{array}{c}\text { Children } \\
\text { everborn }\end{array}$ \\
\hline Age at death of infant and child & 1 & $-0.253^{* *}$ & $-0.248^{* *}$ & 0.43 & $-0.204^{* *}$ & $-0.347^{*}$ & -0.123 \\
\hline Women education & & 1 & $0.688^{* *}$ & $0.314^{* *}$ & $0.209^{* *}$ & $0.177^{* *}$ & $-0.286^{* *}$ \\
\hline Husband education & & & 1 & $0.358^{* *}$ & $0.245^{* *}$ & $0.120^{*}$ & -0.105 \\
\hline Monthly income & & & & 1 & $0.089^{* *}$ & $0.119^{*}$ & -0.047 \\
\hline Age at first marriage & & & & & 1 & 0.152 & $-0.195^{* *}$ \\
\hline Breast feeding & & & & & & & 1 \\
\hline Children everborn & & & & & & & $-0.265^{* *}$ \\
\hline
\end{tabular}

Note: ${ }^{*}$ Significance at $\mathbf{p}<0.01{ }^{* *}$ Significance at $\mathbf{p}<0.05{ }^{* * *}$ Significance at $\mathbf{p}<0.10$

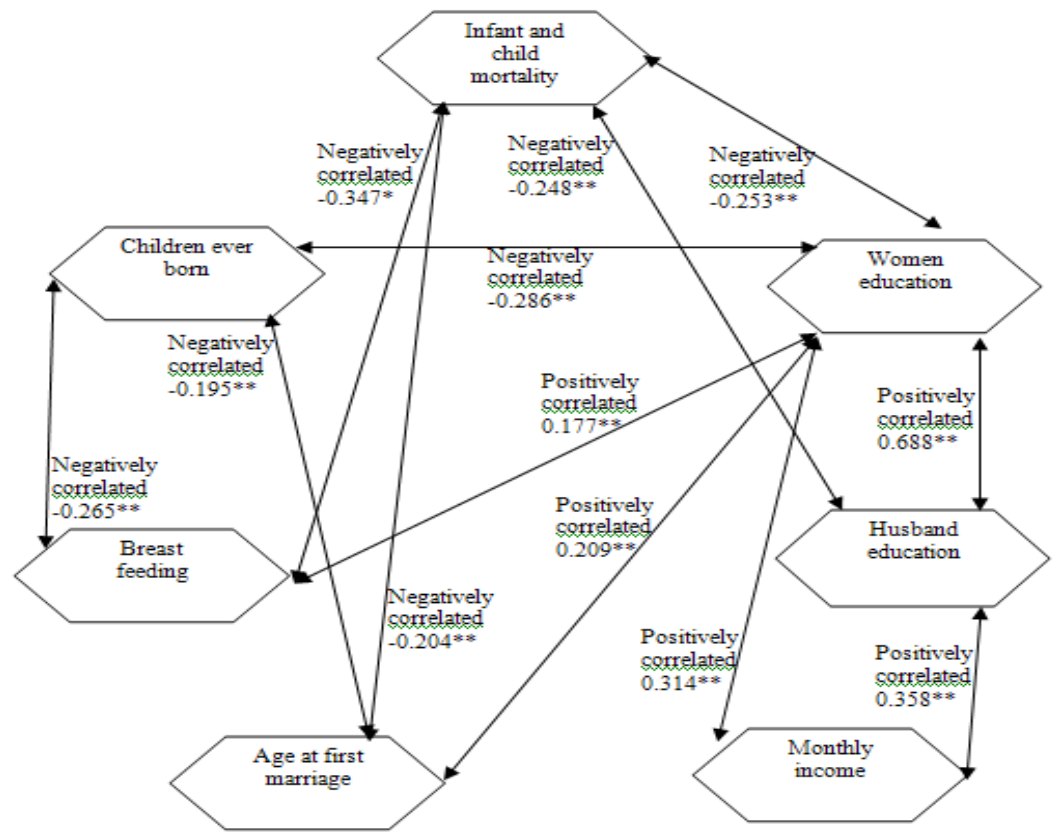

Figure 1. Interrelationship between Socio-economic and Demographic Variables with Infant and Child Mortality 
Table 4. Estimates Multiple Co-Efficient of Determination $\left(\mathrm{R}^{2}\right)$ at age of Death of Infant in Terms of Multiple Covariates

\begin{tabular}{|c|c|c|c|c|c|}
\hline \multirow{2}{*}{ Attributes } & \multicolumn{2}{|c|}{ Multiple correlation coefficient of determination } & \multirow{2}{*}{ Attributes } & \multicolumn{2}{|c|}{ Multiple correlation coefficient of determination } \\
\cline { 2 - 3 } & $\mathbf{R}$ & $\mathbf{R}^{\mathbf{2}}$ & & $\mathbf{R}$ & $\mathbf{R}^{\mathbf{2}}$ \\
\hline $\mathrm{X}_{1,2}$ & 0.388 & 0.150 & $\mathrm{X}_{1,2,5}$ & 0.421 & 0.177 \\
$\mathrm{X}_{1,3}$ & 0.602 & 0.363 & $\mathrm{X}_{1,3,4}$ & 0.665 & 0.442 \\
$\mathrm{X}_{1,4}$ & 0.433 & 0.187 & $\mathrm{X}_{1,3,5}$ & 0.621 & 0.386 \\
$\mathrm{X}_{1,5}$ & 0.311 & .3097 & $\mathrm{X}_{2,3,4}$ & 0.580 & 0.337 \\
$\mathrm{X}_{2,3}$ & 0.549 & $\mathrm{X}_{2,3,5}$ & 0.568 & 0.322 \\
$\mathrm{X}_{2,4}$ & 0.405 & 0.164 & $\mathrm{X}_{2,3,4,5}$ & 0.592 & 0.351 \\
$\mathrm{X}_{2,5}$ & 0.336 & 0.113 & $\mathrm{X}_{1,3,4,5}$ & 0.674 & 0.454 \\
$\mathrm{X}_{3,4}$ & 0.575 & 0.330 & $\mathrm{X}_{1,2,4,5}$ & 0.556 & 0.309 \\
$\mathrm{X}_{3,5}$ & 0.566 & 0.320 & $\mathrm{X}_{1,2,3,5}$ & 0.622 & 0.449 \\
$\mathrm{X}_{1,2,3}$ & 0.602 & 0.363 & $\mathrm{X}_{1,2,3,4}$ & 0.670 & 0.462 \\
$\mathrm{X}_{1,2,4}$ & 0.545 & 0.297 & $\mathrm{X}_{1,2,3,4}$ & 0.68 & \\
\hline
\end{tabular}

Table 5. Estimates Multiple Coefficient of Determination $\left(\mathrm{R}^{2}\right)$ at age of Death of Child in Terms of Multiple Covariates

\begin{tabular}{|c|c|c|c|c|c|}
\hline \multirow{2}{*}{ Attributes } & Multiple correlation co-efficient of determination & \multirow{2}{*}{ Attributes } & \multicolumn{2}{|c|}{ Multiple correlation co-efficient of determination } \\
\cline { 2 - 3 } & $\mathrm{R}$ & $\mathrm{R}^{2}$ & & $\mathrm{R}$ & $\mathrm{R}^{2}$ \\
\hline $\mathrm{X}_{1,2}$ & 0.560 & 0.314 & $\mathrm{X}_{1,2,5}$ & 0.570 & 0.325 \\
$\mathrm{X}_{1,3}$ & 0.788 & 0.621 & $\mathrm{X}_{1,3,4}$ & 0.830 & 0.688 \\
$\mathrm{X}_{1,4}$ & 0.282 & 0.079 & $\mathrm{X}_{1,3,5}$ & 0.793 & 0.629 \\
$\mathrm{X}_{1,5}$ & 0.214 & $\mathrm{X}_{2,3,4}$ & 0.883 & 0.780 \\
$\mathrm{X}_{2,3}$ & 0.828 & 0.685 & $\mathrm{X}_{2,3,5}$ & 0.828 & 0.685 \\
$\mathrm{X}_{2,4}$ & 0.487 & 0.237 & $\mathrm{X}_{2,3,4,5}$ & 0.898 & 0.806 \\
$\mathrm{X}_{2,5}$ & 0.486 & 0.236 & $\mathrm{X}_{1,3,4,5}$ & 0.863 & 0.744 \\
$\mathrm{X}_{3,4}$ & 0.824 & 0.679 & $\mathrm{X}_{1,2,4}$ & 0.590 & 0.348 \\
$\mathrm{X}_{3,5}$ & 0.779 & 0.607 & $\mathrm{X}_{1,2,3,5}$ & 0.855 & 0.731 \\
$\mathrm{X}_{1,2,3}$ & 0.855 & 0.731 & $\mathrm{X}_{1,2,3,4}$ & 0.897 & 0.804 \\
$\mathrm{X}_{1,2,4}$ & 0.570 & 0.325 & $\mathrm{X}_{1,2,3,4}$ & 0.905 & 0.825 \\
\hline
\end{tabular}

\subsection{Impact of Socio-Economic and Demographic Factors on Age at Death of Infant and Child}

From Table 4, it can be seen that the multiple co-efficient of determination of all orders viz. first, second, third and fourth are all statistically significant at 5\% level of significance. All the five covariates age at first marriage, women education, monthly income, breast-feeding and children ever born are taken together explain about $46.2 \%$ of total variation in age at death of infant. CEB explains $44.9 \%$ of total variation while exclusion of age at first marriage explains $35.1 \%$ of the variation. Keeping out of monthly family income explains $30.9 \%$ of total variation. But women education, monthly income and duration of breast-feeding totally explain $45.5 \%$ of the total variation. Women education and monthly income together explain $54.9 \%$, monthly income and duration of breast-feeding explain $57.5 \%$ of the total variation in infant death.

All the five variables, age at first marriage, women education, monthly income, breast-feeding and children ever born are taken together explain about $82.5 \%$ of total variation on age at death of child (Table 5). Execution of CEB explains $80 \%$ of total variation while omission of age at first marriage explains $81 \%$ of the total variation. Absence of monthly income explains $74 \%$ of total variation. Women education, monthly income and duration of breast-feeding totally explain $78 \%$ of the total variation. Women education and monthly income together explain $69 \%$ and monthly income and duration of breast-feeding explain $68 \%$ of the total variation on age at death of child. In the study area, monthly income appears to be the most influential covariate in explaining the variation of death of infant and child in presence of other covariates.

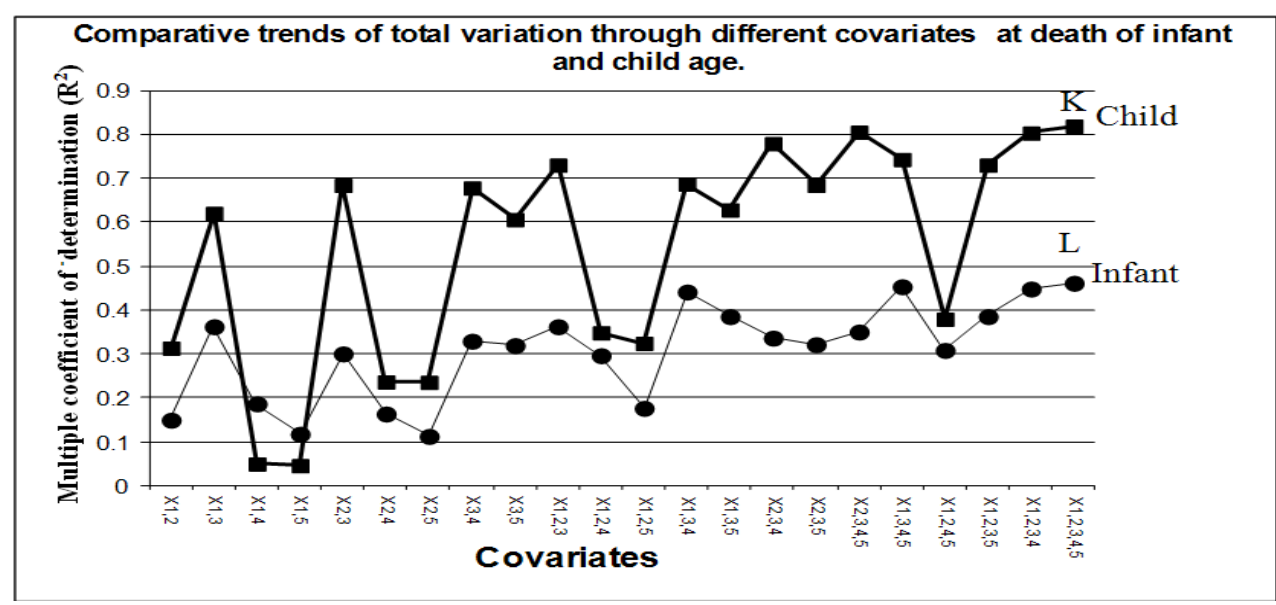

Figure 2. Comparative Patterns of Total Variation at Death of Infant and Child in Terms of Multiple Covariates 


\subsection{Patterns of Death of Infant and Child in Terms of Multiple Covariates}

Child line is conveying total variations at death of child than infant line for infant death. Child line get its highest peak position $\mathrm{K}$, for highest value of $\mathrm{R}^{2}=0.825$ highest peak $\mathrm{K}$ indicate, at the position covariates are age at first marriage, women education, monthly income, breast-feeding, children ever born explain highest $82.5 \%$ of total variation at death of child age. For infant line highest peak $\mathrm{L}$ indicate that at the position covariates are age at marriage, women education, monthly income, breast-feeding, children ever born explain highest $46 \%$ of total variation at death of infant age. Here, child line always keeps upward to the infant line. Now for comparative study of infant and child death, plotting covariates through $\mathrm{X}$-axis and multiple coefficients of determinations $\left(\mathrm{R}^{2}\right)$ through $\mathrm{y}$-axis, we can form the Figure 2.

\section{Conclusions and Policy Implications}

Through differential patterns it can be observed that education of parents, income of household, occupation, age at first marriage and breast-feeding are significantly associated with infant and child death. From correlation analysis, we can see negative significant relationship exist among infant and child mortality with women education, occupation, age at first marriage and breast-feeding. In multiple coefficient of determination $\left(\mathrm{R}^{2}\right)$, all the five covariates: ages at first marriage, women education, monthly income, breast-feeding and children ever born (CEB) are taken together explain about $46 \%$ and $82.5 \%$ of total variation of age at death of infant and child respectively. In comparative graphical presentation of the total variation through different covariates at death of infant and child, child line always keeps upward to infant line.

Therefore, an effective policy and recommendations are needed to reduce infant and child mortality in particular slum areas of Rajshahi district in Bangladesh as well as developing countries. The policy implications and recommendations in this study are given below:

i) For reducing infant and child mortality, different correlated sectors, e.g., health, women education and development, housing, environment, poverty alleviation in slum areas have to be consistently improved.

ii) Provide information and services including counseling services aimed at delaying age at first marriage of women; improved access to reproductive health education that help in reducing infant and child mortality.

iii) Breast-feeding combats with various infectious diseases and strengthen essential antibody system of the child. So, it is necessary to encourage the women to breast feed their child and it will reduce infant and child mortality.

\section{REFERENCES}

[1] United Nations (2008): Population Data Sheet 2008. ESCAP, Thailand

[2] Majumder, A.K. (1989): Determinants of Infant and Child Mortality in Bangladesh. PhD thesis, Australian National University, Canberra

[3] Majumder, A.K. (1990): Child survival and its effect on mortality risks of siblings in Bangladesh. Journal of Biosocial Science 22, 333-347

[4] Majumder, A.K. (1991): Breast-feeding, birth interval and child mortality in Bangladesh. Journal of Biosocial Science $23,297-312$

[5] Majumder, A.K., Haque, M.E. and Hussain, M.I. (1993): Effect of education on infant and child mortality in Bangladesh: an investigation into a causal link. Journal Statistics Study 13, 17-28

[6] Ahmed, R. (2008): Bangladesh: Not on Track to Achieving MDG's Without Debt Relief. Group Report, United States

[7] Wagstaff, A. (2000): Socio-economic inequalities in child mortality: comparisons across nine developing countries. Bull World Health Organ 78, 19-29

[8] Moser K.A., Leon D.A., Gwatkin D.R. (2005): How does progress towards the child mortality millennium development goal affect inequalities between the poorest and least poor? Analysis of Demographic and Health Survey data. BMJ 331, $1180-2$

[9] Fenn, B., Kirkwood, B.R., Popatia, Z., Bradley, D.J. (2007): Inequities in neonatal survival interventions: evidence from national surveys. Arch Dis Child Fetal Neonatal Ed 92, F361-6

[10] Gwatkin, D.R., Rutstein, S., Johnson, K., Suliman, E., Wagstaff, A., Amouzou, A. (2007): Socio-economic differences in health, nutrition and population within developing countries: an overview. Washington, DC: World Bank

[11] Bicego, G.T., Boerma, J.T. (1993): Maternal education and child survival: a comparative study of survey data from 17 countries. Soc Sci Med 36, 1207-27

[12] Caldwell, J.C. (1984): How is greater maternal education translated into lower child mortality? Health Transition Review 4(2) 224-9

[13] Cleland, J.G. and Ginneken, V.J.K. (1988): Maternal education and child survival in developing countries: The search for pathways of influence. Social Science and Medicine 27, $1357-1368$

[14] Cleland, J. and Streatfield, K. (1992): The demographic transition: Bangladesh staff reference series: //92 UNICEF. Dhaka, Bangladesh

[15] Boerma, J.T. and Bicego, G.T. (1992): Preceding birth intervals and child survival: searching for path ways of influence. Studies in Family Planning 23(4), 243-256

[16] Hong and Rathavuth. (2006): Effect of multiple birth on infant mortality in Bangladesh. Journal of Pediatrics and Child Health, 42(10), 630-635(6)

[17] Stockel, J. and Chaudhury, K. M. (1972): Neonatal and post 
neonatal mortality in rural areas of Bangladesh. Population Studies 26, 113-120

[18] Adlakha, A. (1973): Fertility and infant mortality-An analysis of Turkish data. Demography India, 2 56-76

[19] Feeney, G. (1980): Estimating infant mortality trends from child survivorship data. Population Studies 34(1), 109-128

[20] Hobcraft, J.N., McDonald, R.W. and Rustein, S.O. (1985):
Demographic determinants of infant and early child mortality: A comparative analysis. Population Studies 39, 363-386

[21] Rahman, M.M, Islam, M.R. and Ali, M.K. (2005): Effects of demographic characteristics on infant and child mortality: A case study of Rajshahi District, Bangladesh. Journal of Population 12(2), 161-173

[22] Gujarati, D. N. (2003). Basic Econometrics, Third Edition, McGraw Hill, Inc., New York 